Original Research Paper

\title{
Sistem Pendukung Keputusan Pemilihan Guru Terbaik di SMK Pustek Serpong
}

\author{
Fitri Duwiyanti' ${ }^{1}$, Maulana Ardhiansyah ${ }^{1}$ \\ ${ }^{1}$ Program Studi Teknik Informatika, Fakultas Teknik, Universitas Pamulang. \\ Tanggerang Selatan, Indonesia.
}

Article History
Received:
29.03.2019
Revised:
25.05 .2019
Accepted:
06.06 .2019
*Corresponding Author:
Maulana Ardhiansyah
Email:
maulana1402@gmail.com

Abstrak: Dalam upaya meningkatkan mutu pendidikan untuk para siswa sebagai generasi penerus bangsa dibutuhkan guru yang berkompeten dalam memberikan pendidikan kepada siswa. Sistem Pendukung Keputusan di dunia Pendidikan dipandang sebagai aset penting untuk menunjang kelancaran dan keakuratan dalam pencapaian suatu tujuan. SMK Pustek Serpong belum memiliki sistem pendukung keputusan untuk membantu Kepala Sekolah dalam melakukan pemilihan guru terbaik, pengambilan keputusan secara manual akan menghasilkan penilaian yang tidak objektif sehingga tidak tepat. Oleh karena itu, penggunaan metode TOPSIS dapat bermanfaat dalam mendukung sistem pengambilan keputusan dikarenakan metode ini dapat mendukung penilaian kriteria seperti absensi, perilaku, disiplin, kemampuan mengajar dan tanggungjawab guru serta pembobotan nilai. TOPSIS menggunakan prinsip bahwa alternatif terpilih harus mempunyai jarak terdekat dari solusi ideal positif dan jarak terpanjang dari solusi ideal negatif untuk menentukan kedekatan relatif dari suatu alternatif dengan solusi optimal. Hasil yang dicapai dari sistem pendukung keputusan ini adalah sistem ini terbukti dapat membantu SMK Pustek Serpong dalam melakukan pemilihan guru terbaik, penerapan metode TOPSIS terbukti dapat membantu Kepala Sekolah dalam pengambilan keputusan pemilihan guru terbaik.

Kata Kunci: Sistem Pengambilan Keputusan, Seleksi, TOPSIS.

Decision Support System for Selection of the Best Teachers in SMK. Pustek Serpong

Abstract: In an effort to improve the quality of education for students as needed future generation of teachers who are competent in providing education to students. Decision support system (DSS) in the world of education can be seen as an important asset to support the smoothness and accuracy in achieving a goal. SMK Pustek Serpong does not yet have a decision support system to assist principals in the selection of the best teachers, decision making manually will result in an objective assessment that is not appropriate. The use of TOPSIS method in the decision support system is because this method strongly support the assessment of criteria such as absenteeism, attitude, and discipline, teaching ability, and teacher responsibilities, and weighting the value of. TOPSIS uses the principle that the chosen alternative must have the shortest distance from the ideal solution and longest distance from the ideal negative solution to determine the relative proximity of an alternative to the optimal solution. The results archieved from this decision support system is that this system is proven to help SMK Pustek Serpong in the selection of the best teachers, the application of TOPSIS method is proven to help principals in making the best teacher selection decisions.

Keywords: Decision Support System, Selection, TOPSIS. 


\section{Pendahuluan}

Perkembangan ilmu pengetahuan dan teknologi saat ini berlangsung sangat pesat. Hingga saat ini berbagai aspek kehidupan tidak luput dari peranan teknologi. Salah satunya dalam hal pengambilan keputusan. Sistem pendukung keputusan digunakan seorang decision maker dengan berinteraksi secara langsung dengan komputer untuk menciptakan informasi yang berguna dalam membuat keputusan semi terstruktur dan keputusan tak terstruktur yang tidak terantisipasi [1].

Dalam upaya meningkatkan mutu pendidikan untuk para siswa sebagai generasi penerus bangsa dibutuhkan guru yang berkompeten dalam memberikan pendidikan kepada siswa. Guru berprestasi adalah guru yang memiliki kemampuan melaksanakan tugas, keberhasilan dalam melaksanakan tugas, memiliki kepribadian yang sesuai dengan profesi guru dan memiliki wawasan kependidikan sehingga secara nyata mampu meningkatkan mutu proses dan hasil pembelajaran atau bimbingan melebihi yang dicapai oleh guru lain sehingga dapat dijadikan panutan siswa, rekan sejawat, maupun masyarakat sekitarnya [2].

Sistem Pendukung Keputusan (SPK) di dunia pendidikan dapat dipandang sebagai aset penting untuk menunjang kelancaran dan keakuratan dalam pencapaian suatu tujuan [2]. SMK Pustek Serpong belum memiliki sistem pendukung keputusan untuk membantu Kepala Sekolah dalam menentukan guru terbaik. Dibutuhkan sistem pendukung keputusan untuk membantu Kepala Sekolah SMK Pustek Serpong dalam menentukan guru terbaik secara tepat dan akurat dengan metode yang telah ditentukan. Metode yang digunakan untuk sistem pendukung keputusan ini yaitu metode Technique for Order Preference by Similarity to Ideal Solution (TOPSIS). Metode TOPSIS adalah suatu metode untuk mencari solusi ideal berdasarkan nilai preferensi.

\section{Landasan Teori}

Beberapa peneliti telah meneliti penggunaan metode TOPSIS. Martaulina [2] dalam penelitiannya berpandangan bahwa pelaksanaan pemilihan guru berprestasi telah berjalan dengan lancar sesuai dengan kriteria yang telah ditetapkan. Namun demikian, pelaksanaannnya dirasakan masih belum optimal sehingga perlu dilakukan penyempurnaan, khususnya pada aspek penilaian yaitu Tes Tertulis, Tes Wawancara, Presentasi Mengajar, Bahasa Inggris \& TIK. Agar pelaksanaan seleksi guru tersebut dapat berjalan maka perlu adanya suatu sistem pendukung keputusan yang mampu memberikan konsistensi penilaian dengan penerapan normalisasi dan memberikan kemudahan dalam hasil nilai yang akan ditentukan dari setiap tes. Sistem pendukung keputusan yang digunakan dalam penelitian ini adalah dengan menggunakan metode TOPSIS (Technique for Order Preference by Similarity to Ideal Solution). Metode ini sangat mendukung penilaian kriteria dan pembobotan nilai. Kriteria yang digunakan berdasarkan hasil analisa data dan hasil penilaian setiap tes.

Selanjutnya, penelitian oleh Mallu [3] melihat penggunaan metode TOPSIS dalam menentukan keputusan karyawan kontrak menjadi karyawan tetap di PT. Gowa Motor Group. Kemudian, Sihotang [4] meneliti tentang penggunaan metode TOPSIS sebagai sistem pendukung keputusan penerimaan beasiswa. Metode TOPSIS dipilih karena mampu menyeleksi alternatif terbaik dari sejumlah alternatif, dalam hal ini alternatif yang dimaksudkan yaitu yang berhak menerima beasiswa berdasarkan kriteria-kriteria yang ditentukan. Penelitian dilakukan dengan mencari nilai bobot untuk setiap atribut, kemudian dilakukan proses pengurutan kandidat yang akan menentukan alternatif yang optimal, yaitu mahasiswa terbaik.

\subsection{Sistem Pendukung Keputusan}

Sistem Pendukung Keputusan (SPK) atau Decision support system (DSS) merupakan sistem informasi, pemodelan, dan pemanipulasian data. Sistem itu digunakan untuk membantu pengambil keputusan dalam situasi yang semitertstruktur dan situasi yang tidak terstruktur, dimana tidak seorang pun tahu secara pasti bagaimana keputusan seharusnya dibuat.

Aplikasi SPK yang digunakan untuk pengambilan keputusan menggunakan CBIS (Computer Based Information System) yang fleksibel, interaktif dan dapat diadaptasi, yang dikembangkan untuk mendukung solusi atas masalah manajemen spesifik yang tidak terstruktur [5].

Berikut karakteristik yang diharapkan ada didalam SPK [6], yaitu:

1. Dukungan kepada pengambil keputusan, terutama pada situasi semi-terstruktur dan terstruktur, dengan menyertakan penilaian manusia dan informasi terkomputerisasi. Masalah-masalah 
tersebut tidak bisa dipecahkan oleh sistem komputer lain atau metode atau alat kuantitatif standar.

2. Dukungan untuk semua level manajerial, dari eksekutif puncak sampai manajer.

3. Dukungan untuk individu dan kelompok, masalah yang kurang terstruktur sering memerlukan keterlibatan individu dari departemen dan tingkat organisasional yang berbeda atau bahkan dari organisasi lain.

4. Dukungan untuk keputusan independen. Keputusan bisa dibuat satu kali, beberapa kali atau berulang (dalam interval yang sama).

5. Dukungan disemua fase proses pengambilan keputusan : intelegensi, desain, pilihan, dan implementasi.

Sistem pendukung keputusan pada hakekatnya memiliki beberapa tujuan [6], yaitu:

1. Membantu manajer dalam pengambilan keputusan atas masalah semi-terstruktur.

2. Memberikan dukungan atas pertimbangan manajer dan bukan untuk menggantikan fungsi manajer.

3. Meningkatkan efektifitas keputusan yang diambil manajer lebih daripada perbaikan efisiensinya.

4. Kecepatan komputasi. Komputer memungkinkan para pengambil keputusan untuk melakukan banyak komputasi secara cepat dengan biaya rendah.

5. Peningkatan produktivitas. Membangun suatu kelompok pengambil keputusan, terutama para pakar, bisa sangat mahal. Pendukung terkomputerisasi bisa mengurangi ukuran kelompok dan memungkinkan para anggotanya untuk berada diberbagai lokasi yang berbeda-beda (menghemat biaya perjalanan). Selain itu produktivitas staf pendukung (misalnya analis keuangan dan hukum) bisa ditingkatkan menggunakan peralatan optimalisasi yang menentukan cara terbaik untuk menjalankan sebuah bisnis.

\subsection{Fuzzy Multiple Attribute Decision Making}

Fuzzy Multiple Attribute Decision Making (FMADM) adalah suatu metode yang digunakan untuk mencari alternatif optimal dari sejumlah alternatif dengan kriteria tertentu. Inti dari FMADM adalah menentukan nilai bobot untuk setiap atribut, kemudian dilanjutkan dengan proses perankingan yang akan menyeleksi alternatif yang sudah diberikan. Ada beberapa metode yang dapat digunakan untuk menyelesaikan masalah FMADM, dan salah satunya adalah Technique for Order Preference by Similarity to Ideal Solution (TOPSIS) [7].

\subsection{Metode Technique for Order Preference by Similarity to Ideal Solution}

Technique for Order Preference By Similarity To Ideal Solution (TOPSIS) adalah salah satu metode pengambilan keputusan multikriteria, TOPSIS menggunakan prinsip bahwa alternatif terpilih harus mempunyai jarak terdekat dari solusi ideal positif dan jarak terpanjang dari solusi ideal negatif untuk menentukan kedekatan relatif dari suatu alternatif dengan solusi optimal. Solusi ideal positif didefinisikan sebagai jumlah dari seluruh nilai terbaik yang dapat dicapai untuk setiap atribut TOPSIS mempertimbangkan keduanya, jarak terhadap solusi ideal positif dan jarak terhadap solusi ideal negatif dengan mengambil kedekatan relatif terhadap solusi ideal positif [8].

\subsection{Unified Modelling Language}

Unified Modeling Language adalah bahasa standar yang digunakan untuk menjelaskan dan memvisualisasi artifak dari proses analisis dan desain berorientasi objek [9]. UML memungkinkan developer melakukan permodelan secara visual, yaitu penekan pada penggambaran, bukan didominsasi oleh narasi. Diagram-diagram yang digunakan dalam penelitian ini meliputi use case diagram, sequence diagram, activity diagram dan class diagram.

\subsection{Database}

Sebagai suatu kesatuan istilah, basis data (database) sendiri dapat didefinisikan dalam sejumlah sudut pandang [10], antara lain:

1. Himpunan kelompok data (arsip) yang saling berhubungan yang diorganisasi sedemikian rupa kelak dapatdimanfaatkan kembali dengan cepat dan mudah. 
2. Kumpulan data saling berhubungan yang disimpan secara bersama sedemikian rupa tanpa pengulangan (redudansi) yang tidak perlu untuk memenuhi berbagai kebutuhan.

3. Kumpulan file/tabel/arsip yang saling berhubungan yang disimpan dalam media penyimpanan elektronis.

Basis data yang digunakan dalam penelitian ini adalah Entity Relationship Diagram (ERD), Transformasi ERD ke LRS, dan Logical Record Structure (LRS).

\section{Perancangan dan Implementasi}

Sistem Pendukung Keputusan untuk memilih guru berprestasi di pada SMK Pustek Serpong masih menggunakan sistem manual. Gambar 1 menunjukkan urutan kejadian pada saat seorang Kepala Sekolah melakukan penilaian guru secara langsung.

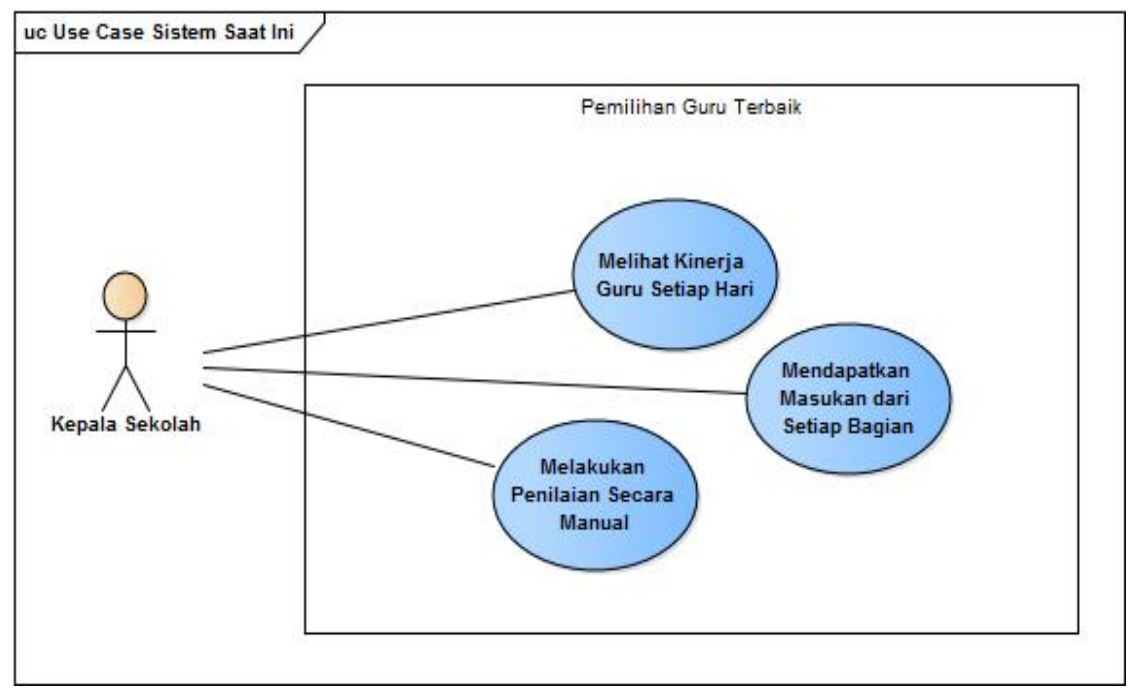

Gambar 1. Use Case Diagram Sistem Berjalan

Setelah dilakukan penelitian, ditemukan beberapa hal yang terjadi diantaranya:

1. Belum adanya sistem yang digunakan sebagai rekomendasi kepada Kepala Sekolah dalam hal melakukan pemilihan guru terbaik.

2. Kepala Sekolah mendapat kendala menentukan seseorang guru terbaik karena belum adanya metode penilaian yang dapat memproses penilaian guru terbaik.

3. Proses penilaian perhitungan berdasarkan kriteria tanpa menggunakan suatu metode tertentu, sehingga dibutuhkan sistem pendukung keputusan untuk penilaian guru terbaik.

Setelah mengetahui sistem manual yang berjalan dan telah dievaluasi maka usulan pemecahan masalah pada sistem manual tersebut, akan dibuat aplikasi sistem pendukung keputusan yang dapat membantu Kepala Sekolah untuk menentukan guru yang paling layak direkomendasikan menjadi guru terbaik.

Sistem yang diusulkan untuk menentukan pemilihan guru terbaik pada SMK Pustek Serpong dibagi menjadi 4 pengguna, yaitu super admin sistem yang mengelola semua data, Admin yaitu petugas TU yang melakukan penilaian, Kepala Sekolah sebagai user yang mendapatkan laporan hasil penilaian, dan Guru sebagai user untuk melihat hasil penilaian mereka.

Diagram sistem yang diusulkan dapat dilihat pada Gambar 2, Gambar 3, Gambar 4, dan Gambar 5. 
Fitri Duwiyanti, Maulana Ardhiansyah.

Decision Support System for Selection of the Best Teachers in SMK. Pustek Serpong.

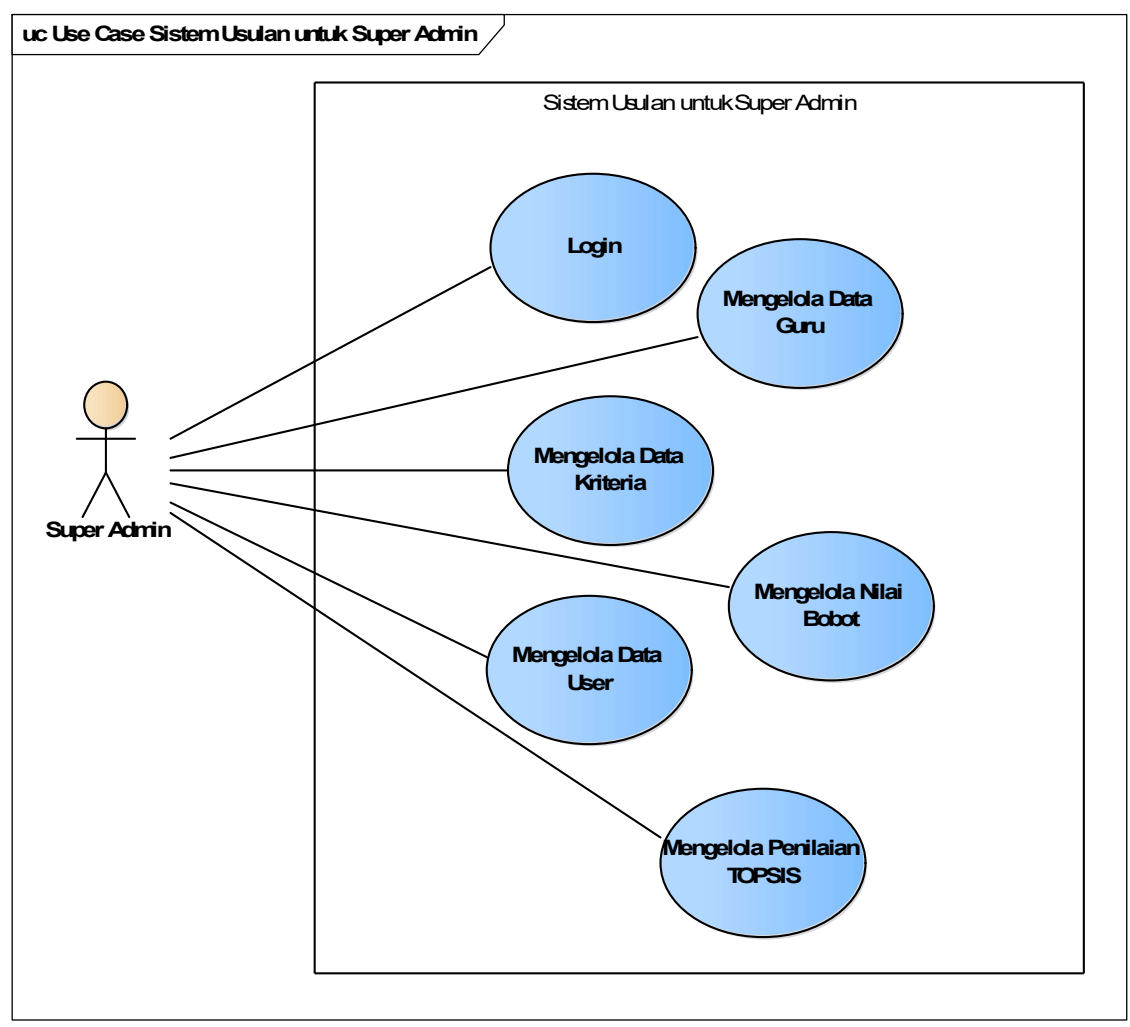

Gambar 2. Sistem Yang Diusulkan Untuk Super Admin

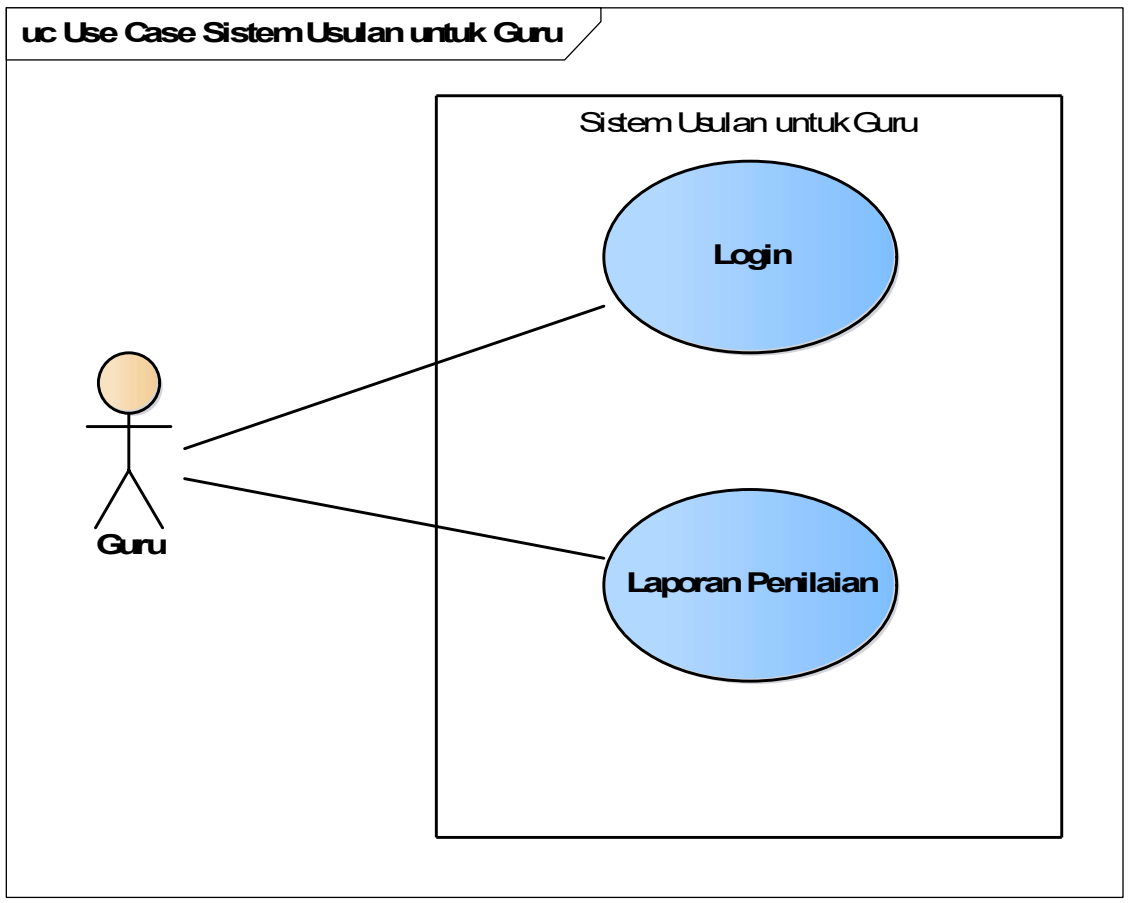

Gambar 3. Sistem Yang Diusulkan Untuk Guru 
Fitri Duwiyanti, Maulana Ardhiansyah.

Decision Support System for Selection of the Best Teachers in SMK. Pustek Serpong.

International Journal of Education, Science, Technology and Engineering, vol. 2, no. 1, pp. 45-67, June 2019. DOI: 10.36079/lamintang.ijeste-0201.18

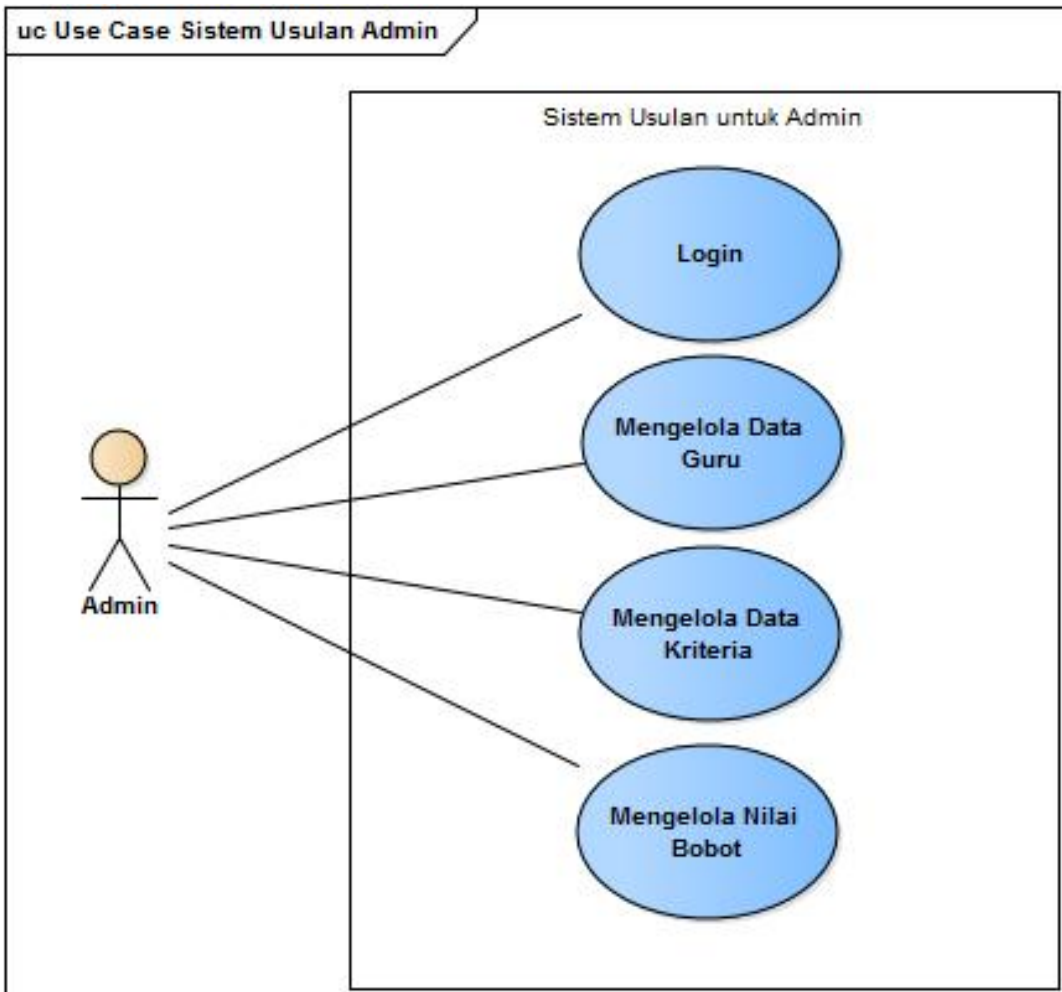

Gambar 4. Sistem Yang Diusulkan Untuk Admin

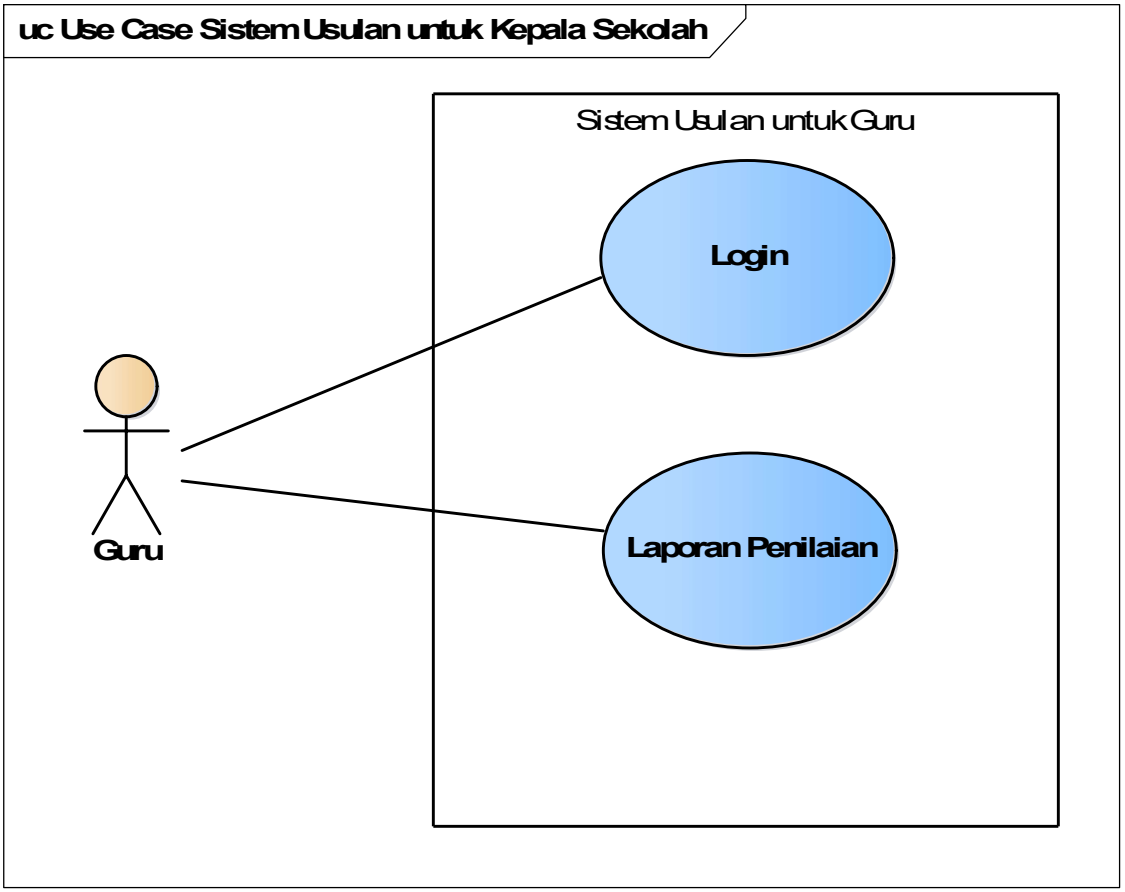

Gambar 5. Sistem Yang Diusulkan Untuk Kepala Sekolah 


\section{Perancangan Sistem Pendukung Keputusan dengan Menggunakan Metode TOPSIS}

Dalam menentukan guru terbaik dengan menggunakan metode Technique for Order Preference by Similarity to Ideal Solution (TOPSIS) diperlukan kriteria-kriteria dan bobot untuk melakukan perhitungan sehingga akan didapat alternatif terbaik untuk pemilihan guru terbaik.

Kriteria dan bobot pada penilaian kinerja guru SMK Pustek Serpong ditunjukkan pada Tabel 1.

Tabel 1. Kriteria

\begin{tabular}{|c|l|}
\hline Kriteria & \multicolumn{1}{|c|}{ Keterangan } \\
\hline $\mathrm{C} 1$ & Absensi \\
\hline $\mathrm{C} 2$ & Perilaku \\
\hline $\mathrm{C} 3$ & Disiplin \\
\hline $\mathrm{C} 4$ & Kemampuan Mengajar \\
\hline $\mathrm{C} 5$ & Tanggung Jawab \\
\hline
\end{tabular}

Untuk penilaian kriteria Absensi ditentukan berdasarkan niali rill dan untuk penilaian kriteria seperti Disiplin, Perilaku, Tanggung Jawab, Kemampuan Mengajar ditentukan berdasarkan bilangan fuzzy yaitu sangat rendah (SR), rendah (R), cukup (C), baik (B), sangat baik (SB) seperti pada Gambar 6.

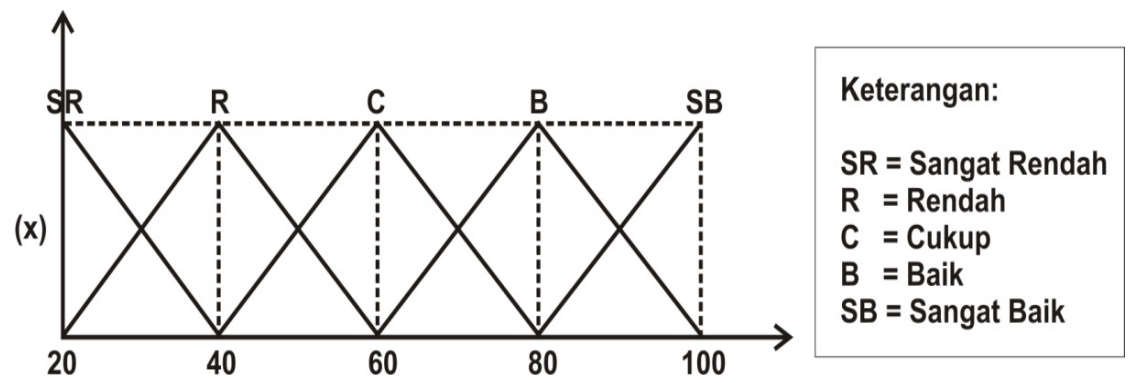

Gambar 6. Bilangan Fuzzy Untuk Ketentuan Nilai Setiap Alternatif

Bilangan fuzzy pada Gambar 6 ditujukan untuk pembobotan dari masing-masing bilangan fuzzy yang sudah ditentukan sebelumnya pada tabel kriteria. Nilai crips tersebut bertujuan untuk memberikan nilai keanggotaan pada setiap bilangan fuzzy.

Langkah-langkah dalam perhitungan penilaian pegawai terbaik berdasarkan penilaian kinerja guru dengan menggunakan metode Technique for Order Preference by Similarity to Ideal Solution (TOPSIS), maka yang harus dilakukan yaitu:

1. Menentukan alternatif yang dijadikan penilaian kinerja guru. Alternatif yang digunakan merupakan nama guru SMK Pustek Serpong.

2. Memberikan nilai setiap alternatif pada setiap kriteria yang ditentukan.

Tabel 2. Rating Kecocokan Nilai Setiap Kriteria

\begin{tabular}{|c|l|}
\hline Kriteria & \multicolumn{1}{|c|}{ Bilangan Fuzzy } \\
\hline 1 & Sangat Rendah \\
\hline 2 & Rendah \\
\hline 3 & Cukup \\
\hline 4 & Baik \\
\hline 5 & Sangat Baik \\
\hline
\end{tabular}


Fitri Duwiyanti, Maulana Ardhiansyah.

Decision Support System for Selection of the Best Teachers in SMK. Pustek Serpong

Tahap selanjutnya adalah menentukan kriteria dalam penilaian guru terbaik. Kemudian memberikan nilai setiap alternatif pada setiap kriteria yang sudah ditentukan seperti yang ditunjukkan pada Tabel 3 .

Tabel 3. Nilai Alternatif Pada Setiap Kriteria

\begin{tabular}{|c|c|c|}
\hline Kriteria & Nilai & Keterangan \\
\hline Absensi & 100 & Sangat Baik \\
\hline Perilaku & 60 & Cukup \\
\hline Disiplin & 80 & Baik \\
\hline Kemampuan Mengajar & 60 & Cukup \\
\hline Tanggung Jawab & 80 & Baik \\
\hline
\end{tabular}

Tahap selanjutnya adalah memberikan nilai bobot (W). Untuk menentukan nilai bobot pada setiap kriteria-kriteria yang telah ditentukan pada tabel kriteria, maka penentuan pembobotan dibagi menjadi 5 bilangan fuzzy, yaitu Sangat Rendah (SR), Rendah (R), Cukup (C), Tinggi (T), Sangat Tinggi (ST), seperti pada Gambar 7.

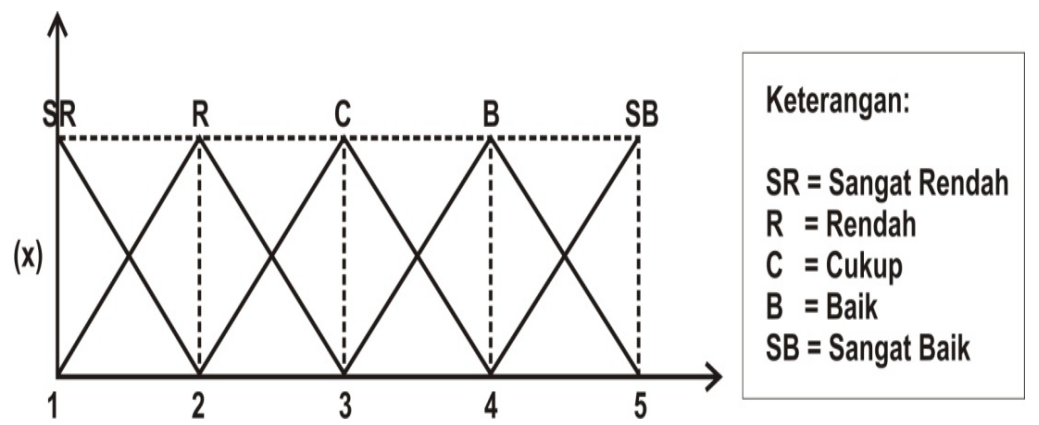

Gambar 7. Bilangan Fuzzy Untuk Ketentuan Bobot Setiap Kriteria

Tabel 4. Rating Kecocokan Bobot Kriteria

\begin{tabular}{|c|c|}
\hline Nilai & Bilangan Fuzzy \\
\hline 1 & Sangat Rendah \\
\hline 2 & Rendah \\
\hline 3 & Cukup \\
\hline 4 & Tinggi \\
\hline 5 & Sangat Tinggi \\
\hline
\end{tabular}

Tabel 5. Bobot Kriteria

\begin{tabular}{|c|c|c|}
\hline Kriteria & Nilai Bobot & Keterangan \\
\hline Absensi & 5 & Sangat Baik \\
\hline Perilaku & 3 & Cukup \\
\hline Disiplin & 4 & Baik \\
\hline Kemampuan Mengajar & 3 & Cukup \\
\hline Tanggung Jawab & 4 & Baik \\
\hline
\end{tabular}


Dari Tabel 5 disimpulkan bahwa pengambil keputusan memberikan bobot (W) preferensi sebagai berikut:

$$
\mathrm{W}=\{3,5,5,4,4\}
$$

Nilai $\mathrm{W}$ adalah nilai pada tabel bobot kriteria. Dan menghasilkan nilai 3 untuk $\mathrm{C} 1,5$ untuk $\mathrm{C} 2,5$ untuk C3, 4 untuk $\mathrm{C} 4,4$ untuk $\mathrm{C} 5$.

Tahap selanjutnya adalah merancang matrik ternormalisasi dengan menggunakan Persamaan 1.

$$
r_{i j}=\frac{x_{i j}}{\sqrt{\sum_{1=1}^{m} x_{y j}^{2}}}
$$

2.

Yang diikuti dengan, merancang matriks ternormalisasi terbobot dengan menggunakan Persamaan

$y_{i j}=w_{i} r_{i j}$

dengan ketentuan,

$y_{i j}=$ matriks ternormalisasi terbobot

$w_{i}=$ bobot subjektif

Tahap berikutnya adalah menghitung matriks solusi ideal positif dan matriks solusi ideal negatif, dengan menggunakan Persamaan 3.

$$
\begin{aligned}
& y_{i j}=w_{i} r_{i j} \\
& A^{+}=\left(y_{1}^{+}, y_{2}^{+}, \ldots, y_{n}^{+}\right) ; \\
& A^{-}=\left(y_{1}^{-}, y_{2}^{-}, \ldots, y_{n}^{-}\right) ;
\end{aligned}
$$

dengan ketentuan:

$$
\begin{aligned}
y_{j}^{+} & =\left\{\begin{array}{l}
\max y_{i j} ; j i k a j \text { adalah atribut kountungan } \\
\min y_{i j} ; \text { jika } j \text { adalah atribut biaya }
\end{array}\right. \\
y_{j}^{-} & =\left\{\begin{array}{l}
\min y_{i j} ; j i k a j \text { adalah atribut keuntungan } \\
\max y_{i j} ; j i k a j \text { adalah atribut biaya }
\end{array}\right.
\end{aligned}
$$

Tahap selanjutnya adalah menentukan jarak solusi ideal positif dan negatif dengan menggunakan Persamaan 4.

$$
D_{i}^{+}=\sqrt{\sum_{j=1}^{n}\left(y_{i}^{+}-y_{i j}\right)^{2}}
$$

Dan kemudian menghitung preferensi dengan menggunakan Persamaan 5.

$$
V_{i}=\frac{D_{i}^{-}}{D_{i}^{-} \mid D_{i}^{+}}
$$

Untuk menganalisa dan mengetahui hasil penerapan metode TOPSIS dalam menentukan penilaian guru terbaik, maka dilakukan penerapan pada guru di SMK Pustek Serpong. Dari jumlah 60 guru di SMK Pustek Serpong diambil 5 guru sebagai sampel untuk penerapan metode TOPSIS dalam penentuan pemilihan guru terbaik. Data-data sampel dapat dilihat pada Tabel 6. 
Tabel 6. Data Sampling

\begin{tabular}{|c|c|c|c|c|c|}
\hline \multirow[b]{2}{*}{. } & \multicolumn{5}{|c|}{ Kriteria } \\
\hline & 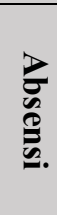 & $\frac{\text { Q }}{3}$ & $\begin{array}{l}\text { ㅋ.ᅳ. } \\
\text { 를. }\end{array}$ & 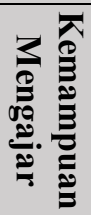 & 绨 \\
\hline & 1 & 5 & 4 & 3 & 2 \\
\hline & 2 & 1 & 5 & 4 & 3 \\
\hline & 3 & 2 & 1 & 5 & 4 \\
\hline & 4 & 3 & 2 & 1 & 5 \\
\hline & 5 & 4 & 3 & 2 & 1 \\
\hline Bobot $=W$ & 3 & 5 & 5 & 4 & 4 \\
\hline
\end{tabular}

Tahap selanjutnya adalah menormalisasi matriks $\mathrm{X}$ menjadi matriks $\mathrm{R}$ dengan menggunakan Persamaan 6.

$$
\begin{aligned}
& {[X 1]=\sqrt{1^{2}+2^{2}+3^{2}+4^{2}+5^{2}}} \\
& =\sqrt{1+4+9+16+25} \\
& =\sqrt{55}=7,4162 \\
& r_{11}=\frac{1}{7,4162}=0,4045 \\
& r_{21}=\frac{2}{7,4162}=0,2697 \\
& r_{31}=\frac{3}{7_{4} 4162}=0,4045 \\
& r_{41}=\frac{4}{7,4162}=0,5393 \\
& r_{51}=\frac{5}{7,4162}=0,6742 \\
& {[X 2]=\sqrt{5^{2}}+1^{2}+2^{2}+3^{2}+4^{2}} \\
& =\sqrt{25+1+4+9+16} \\
& =\sqrt{55}=7,4167 \\
& r_{12}=\frac{5}{7,4162}=0,6742 \\
& r_{22}=\frac{1}{7,4162}=0,4045 \\
& r_{32}=\frac{2}{7,4162}=0,2697 \\
& r_{42}=\frac{3}{7,4162}=0,4045 \\
& r_{52}=\frac{4}{7,4162}=0,5393 \\
& {[X 3]=\sqrt{4^{2}+5^{2}+1^{2}+2^{2}+3^{2}}} \\
& =\sqrt{16+25+1+4+9} \\
& =\sqrt{55}=7,4162 \\
& r_{13}=\frac{4}{7,4162}=0,5393 \\
& r_{23}=\frac{5}{7,4162}=0,6742 \\
& r_{31}=\frac{1}{7,4162}=0,4045 \\
& r_{41}=\frac{2}{7,4162}=0,2697 \\
&
\end{aligned}
$$




$$
\begin{aligned}
& r_{51}=\frac{3}{7,4162}=0,4045 \\
& {[X 4]=\sqrt{3^{2}+4^{2}+5^{2}+1^{2}+2^{2}}} \\
& =\sqrt{9+16+25+1+4} \\
& =\sqrt{55}=7,4162 \\
& r_{14}=\frac{3}{7,4162}=0,4045 \\
& r_{24}=\frac{4}{7,4162}=0,5393 \\
& r_{34}=\frac{\frac{5}{7,4162}}{7_{14}}=0,6742 \\
& r_{44}=\frac{1}{7,4162}=0,4045 \\
& r_{51}=\frac{2}{7,4162}=0,2697 \\
& {[X 5]=\sqrt{2^{2}}+3^{2}+4^{2}+5^{2}+1^{2}} \\
& =\sqrt{4+9+16+25+1} \\
& =\sqrt{55}=7,4162 \\
& r_{15}=\frac{2}{7,4162}=0,2697 \\
& r_{25}=\frac{3}{7,4162}=0,4045 \\
& r_{35}=\frac{4}{7,4162}=0,5393 \\
& r_{45}=\frac{5}{7,4162}=0,6742 \\
& r_{55}=\frac{1}{7,4162}=0,4045
\end{aligned}
$$

Maka, didapatkan matriks R:

$$
R=\left\{\begin{array}{lllll}
0,4045 & 0,6742 & 0,5393 & 0,4045 & 0,2697 \\
0,2697 & 0,4045 & 0,6742 & 0,5393 & 0,4045 \\
0,4045 & 0,2697 & 0,4045 & 0,6742 & 0,5393 \\
0,5393 & 0,4045 & 0,2697 & 0,4045 & 0,6742 \\
0,6742 & 0,5393 & 0,4045 & 0,2697 & 0,4045
\end{array}\right\}
$$

Tahap selanjutnya adalah menormalisasi matriks $\mathrm{R}$ menjadi matriks terbobot $\mathrm{Y}$ dengan menggunakan Persamaan 7.

$$
\begin{aligned}
& y_{i j}=W_{i} r_{i j} \\
& y_{11}=3 \times 0,4045=1,2135 \\
& y_{21}=3 \times 0,2697=0,8091 \\
& y_{31}=3 \times 0,4045=1,2135 \\
& y_{41}=3 \times 0,5393=1,6179 \\
& y_{51}=3 \times 0,6742=2,0226 \\
& y_{12}=5 \times 0,6742=3,371 \\
& y_{22}=5 \times 0,4045=2,0225 \\
& y_{32}=5 \times 0,2697=1,3485 \\
& y_{42}=5 \times 0,4045=2,0225 \\
& y_{52}=5 \times 0,5393=2,6965 \\
& y_{13}=5 \times 0,5393=2,6965 \\
& y_{23}=5 \times 0,6742=3,371 \\
& y_{33}=5 \times 0,4045=2,0225 \\
& y_{43}=5 \times 0,2697=1,3485 \\
& y_{53}=5 \times 0,4045=2,0225
\end{aligned}
$$




$$
\begin{aligned}
& y_{14}=4 \times 0,4045=1,618 \\
& y_{24}=4 \times 0,5393=2,1572 \\
& y_{34}=4 \times 0,6742-2,6968 \\
& y_{44}=4 \times 0,4045=1,618 \\
& y_{54}=4 \times 0,2697=1,0788 \\
& y_{15}=4 \times 0,2697=1,0788 \\
& y_{25}=4 \times 0,4045=1,618 \\
& y_{35}=4 \times 0,5393=2,1572 \\
& y_{45}=4 \times 0,6742=2,6968 \\
& y_{55}=4 \times 0,4045=1,618
\end{aligned}
$$

Maka, didapatkan matriks $y$ terbobot:

$$
R=\left\{\begin{array}{ccccc}
1,2135 & 3,371 & 2,6965 & 1,618 & 1,0788 \\
0,3091 & 2,0225 & 3,371 & 2,1572 & 1,618 \\
1,2135 & 1,3485 & 2,0225 & 2,6968 & 2,1572 \\
1,6179 & 2,0225 & 1,3485 & 1,618 & 2,6968 \\
2,0226 & 2,6965 & 2,0225 & 1,0788 & 1,618
\end{array}\right\}
$$

Tahap selanjutnya adalah mencari solusi ideal positif $\left(\mathrm{A}^{+}\right)$dan solusi ideal negatif $\left(\mathrm{A}^{-}\right)$ berdasarkan Persamaan 8 dan Persamaan 9.

$$
\begin{aligned}
& A^{+}=\left(y_{1}^{+}, y_{2}^{+}, \ldots, y_{n}^{+}\right) ; \\
& A^{-}=\left(y_{1}^{-}, y_{2}^{-}, \ldots, y_{n}^{-}\right) ;
\end{aligned}
$$

Kemudian akan diperoleh, solusi ideal positif,

$$
\begin{aligned}
& y_{1}^{+}=\max \{1,2135 ; 0,8091 ; 1,2135 ; 1,6179 ; 2,0226\}=2,0226 \\
& y_{2}^{+}=\max \{3,371 ; 2,0225 ; 1,3485 ; 2,0225 ; 2,6965\}=3,371 \\
& y_{5}^{+}=\max \{2,6965 ; 3,371 ; 2,0225 ; 1,3485 ; 2,0225\}=3,371 \\
& y_{4}^{+}=\max \{1,618 ; 2,1572 ; 2,6968 ; 1,618 ; 1,0788\}=2,6968 \\
& y_{5}^{+}=\max \{1,0788 ; 1,618 ; 2,1572 ; 2,6968 ; 1,618\}=2,6968 \\
& \left(A^{+}\right)=\{2,0226 ; 3,371 ; 3,371 ; 2,6968 ; 2,6968]
\end{aligned}
$$

dan solusi ideal negatif

$$
\begin{aligned}
& y_{1}^{-}-\min \{1,2135 ; 0,8091 ; 1,2135 ; 1,6179 ; 2,0226\}-0,8091 \\
& y_{2}^{-}=\min \{3,371 ; 2,0225 ; 1,3485 ; 2,0225 ; 2,6965\}=1,3485 \\
& y_{8}^{-}=\min \{2,6965 ; 3,371 ; 2,0225 ; 1,3485 ; 2,0225\}=1,3485 \\
& y_{4}^{-}=\min \{1,618 ; 2,1572 ; 2,6968 ; 1,618 ; 1,0788\}=1,0788 \\
& y_{5}^{-}=\min \{1,0788 ; 1,618 ; 2,1572 ; 2,6968 ; 1,618\}=1,0788 \\
& \left(A^{-}\right)=\{1,0884 ; 0,9258 ; 1,846 ; 1,2648 ; 0,8163\}
\end{aligned}
$$

Tahap berikutnya adalah mencari jarak alternatif $A_{i}$ dengan solusi ideal positif dan jarak alternatif $\mathrm{A}_{\mathrm{i}}$ dengan solusi ideal negatif berdasarkan Persamaan 10.

$$
D_{i}^{+}=\sqrt{\sum_{j=1}^{n}\left(y_{i j}-y_{i}^{-}\right)^{2}}
$$

Sehingga diperoleh nilai- nilai $D_{i}^{+}$: 


$$
\begin{aligned}
& D_{1}^{+}=\sqrt{\begin{array}{c}
(2,0226-1,2135)^{2}+(3,371-3,371)^{2}+ \\
(3,371-2,6965)^{2}+(2,6968-1,618)^{2}+ \\
(2,6968-1,0 / 88)^{2}
\end{array}} \\
& =\sqrt{(0,6546)+(0)+(0,4549)+(1,1634)+(2,6179)} \\
& =\sqrt{4,8906}=2,2115
\end{aligned}
$$

$$
\begin{aligned}
& D_{2}^{+}=\sqrt{\begin{array}{c}
(2,0226-0,8091)^{2}+(3,371-2,0225)^{2}+ \\
\left.(3,371 \quad 3,371)^{2} I_{(2,6968} 2,1572\right)^{2} \\
(2,6968-1,618)^{2}
\end{array}} \\
& =\sqrt{(1,4726)+(1,8185)+(0)+(0,2912)+(1,1638)} \\
& =\sqrt{4,7461}=2,1785
\end{aligned}
$$

$$
\begin{aligned}
& D_{3}^{+}=\sqrt{\begin{array}{c}
(2,0226-1,2135)^{2}+(3,371-1,3485)^{2}+ \\
(3,371-2,0225)^{2}+(2,6968-2,6968)^{2}+ \\
(2,69682,1572)^{2}
\end{array}} \\
& =\sqrt{(0,6546)+(4,0905)+(1,8185)+(0)+(0,2917)} \\
& -\sqrt{6,0553}-2,6103
\end{aligned}
$$

$$
\begin{aligned}
& D_{4}^{+}=\sqrt{\begin{array}{c}
(2,0226-1,6179)^{2}+(3,371-2,0225)^{2}+ \\
(3,371-1,3485)^{2}+(2,6968-1,618)^{2}+ \\
(2,6968-2,6968)^{2}
\end{array}} \\
& =\sqrt{(0,1638)+(1,8185)+(4,0905)+(1,1634)+(0)} \\
& =\sqrt{7,2362}=2,6900
\end{aligned}
$$

$$
\begin{aligned}
& D_{5}^{+}=\sqrt{\begin{array}{c}
(2,0226-2,0226)^{2}+(3,371-2,6965)^{2}+ \\
(3,371-2,0225)^{2}+(2,6968-1,0788)^{2}+ \\
(2,6968-1,618)^{2}
\end{array}} \\
& =\sqrt{(0)+(0,4549)+(1,8185)+(2,6179)+(1,1634)} \\
& =\sqrt{6,0547}=2,4606
\end{aligned}
$$

dan nilai- nilai nilai $D_{i}^{-}$:

$$
\begin{aligned}
& D_{1}^{-}=\sqrt{\begin{array}{c}
(1,2135-0,8091)^{2}+(3,371-1,3485)^{2}+ \\
(2,6965-1,3485)^{2}+(1,618-1,0788)^{2}+ \\
(1,0788-1,0788)^{2}
\end{array}} \\
& =\sqrt{(0,1635)+(4,0905)+(1,8171)+(0,2907)+(0)} \\
& =\sqrt{6,3618}=2,5223
\end{aligned}
$$




$$
\begin{aligned}
& D_{2}^{-}=\sqrt{\begin{array}{c}
(0,8091-0,8091)^{2}+(2,0225-1,3485)^{2}+ \\
(3,371-1,3485)^{2}+(2,1572-1,0788)^{2}+ \\
(1,618-1,0 / 88)^{2}
\end{array}} \\
& =\sqrt{(0)+(0,4543)+(4,0905)+(1,1629)+(0,2907)} \\
& =\sqrt{5,9984}=2,4492
\end{aligned}
$$

$$
\begin{aligned}
& D_{3}^{-}-\sqrt{\begin{array}{c}
(1,2135-0,8091)^{2}+(1,3485-1,3485)^{2}+ \\
(2,0225-1,3405)^{2}+(2,6968-1,0700)^{2}+ \\
(2,1572-1,0788)^{2}
\end{array}} \\
& =\sqrt{(0,1635) \text { I }(0) \mathrm{I}(0,4543) \mathrm{I}(2,6179) \mathrm{I}(1,1629)} \\
& =\sqrt{4,3986}=2,0973
\end{aligned}
$$

$$
\begin{aligned}
& D_{4}^{-}=\sqrt{\begin{array}{c}
(1,6179-0,8091)^{2}+(2,0225-1,3485)^{2}+ \\
(1,3485-1,3485)^{2}+(1,618-1,0788)^{2}+ \\
(2,6968-1,0788)^{2}
\end{array}} \\
& =\sqrt{(0,6541)+(0,4543)+(0)+(0,2907)+(2,6179)} \\
& =\sqrt{4,017}=2,0042
\end{aligned}
$$

$$
\begin{aligned}
& D_{5}^{-}=\sqrt{\begin{array}{c}
(2,0226-0,8091)^{2}+(2,6965-1,3485)^{2}+ \\
(2,0225-1,3485)^{2}+(1,0788-1,0788)^{2}+ \\
(1,618-1,0788)^{2}
\end{array}} \\
& =\sqrt{(1,4726)+(1,8171)+(0,4543)+(0)+(0,2907)} \\
& =\sqrt{4,0347}=2,0086
\end{aligned}
$$

Tahap berikutnya adalah mencari nilai preferensi untuk setiap alternatif $\left(\mathrm{V}_{\mathrm{i}}\right)$ berdasarkan Persamaan 11.

$$
V_{i}=\frac{D_{i}^{-}}{D_{i}^{-}+D_{i}^{+}}
$$

$$
\begin{aligned}
& V_{1}-\frac{2,5223}{2,5223+2,2115}-\frac{2,5223}{4,7338}-0,5328 \\
& V_{2}=\frac{2,4492}{2,4492+2,1785}=\frac{2,4492}{4,6277}=0,5292 \\
& V_{3}=\frac{2,09 / 3}{2,0973+2,6183}=\frac{2,09 / 3}{4,7156}=0,4447 \\
& V_{4}-\frac{2,0042}{2,0042+2,6900}-\frac{2,0042}{4,6942}-0,4269 \\
& V_{5}=\frac{2,0086}{2,0086+2,4606}=\frac{2,0085}{4,4692}=0,4494
\end{aligned}
$$

Hasil lengkap seperti pada Tabel 7. 
Tabel 7. Hasil Perankingan

\begin{tabular}{|c|c|}
\hline Alternatif & Nilai \\
\hline$V_{1}$ & 0,5328 \\
\hline$V_{2}$ & 0,5292 \\
\hline$V_{3}$ & 0,4447 \\
\hline$V_{4}$ & 0,4269 \\
\hline$V_{5}$ & 0,4494 \\
\hline
\end{tabular}

Berdasarkan data pada Tabel 7 diperoleh bahwa berdasarkan hasil perhitungan metode Technique for Order Preference by Similarity to Ideal Solution (TOPSIS) yang memiliki nilai tertinggi adalah guru ke -1 dengan nilai 0,5328 dan berhak direkomendasikan sebagai guru terbaik.

\section{Perancangan Sistem}

Perancangan Basis Data meliputi perancangan Entity Relationship Diagram (ERD), Transformasi ERD ke LRS, Logical Record Structure, dan spesifikasi Basis Data yang digunakan. Diagram ERD diatas menggambarkan struktur database yang akan dibangun dalam sistem perhitungan pemilihan guru terbaik.

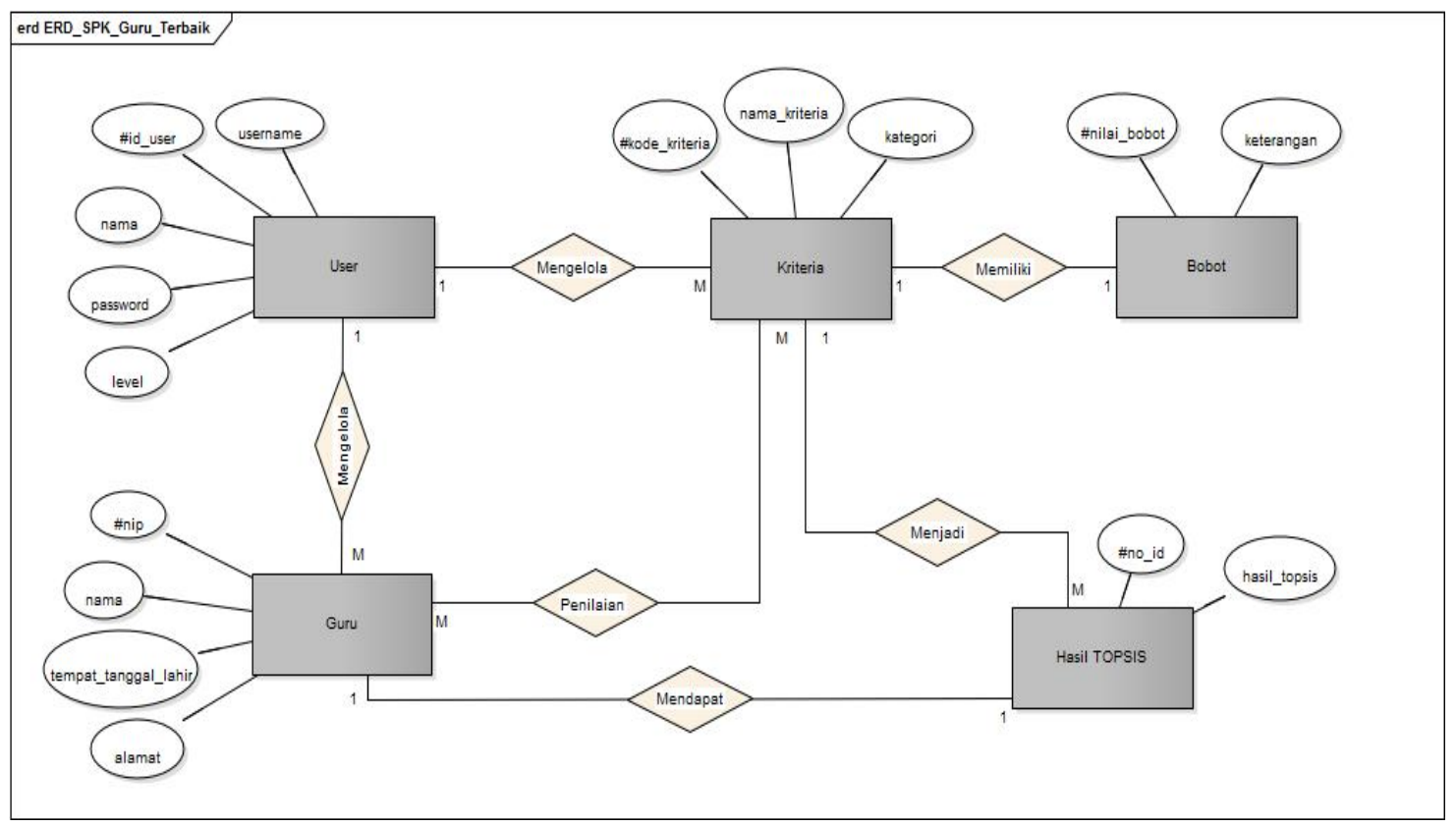

Gambar 8. Entity Relationship Diagram

Gambar 9 menampilkan gambar transformasi ERD (Entity Relationship Diagram) diubah kebentuk LRS (Logical Record Structure).

Setelah ditransformasikan ERD ke LRS, maka bentuk Logical Record Structure (LRS) yang sudah terbentuk adalah seperti pada Gambar 10.

Spesifikasi basis data mengelompokkan uraian rinci setiap tabel. Tabel adalah komponen utama dan pertama dari sebuah database. Tabel 8 adalah salah satu contoh struktur tabel yang terdapat dalam database sistem yang dibangunkan. 
Fitri Duwiyanti, Maulana Ardhiansyah.

Decision Support System for Selection of the Best Teachers in SMK. Pustek Serpong.

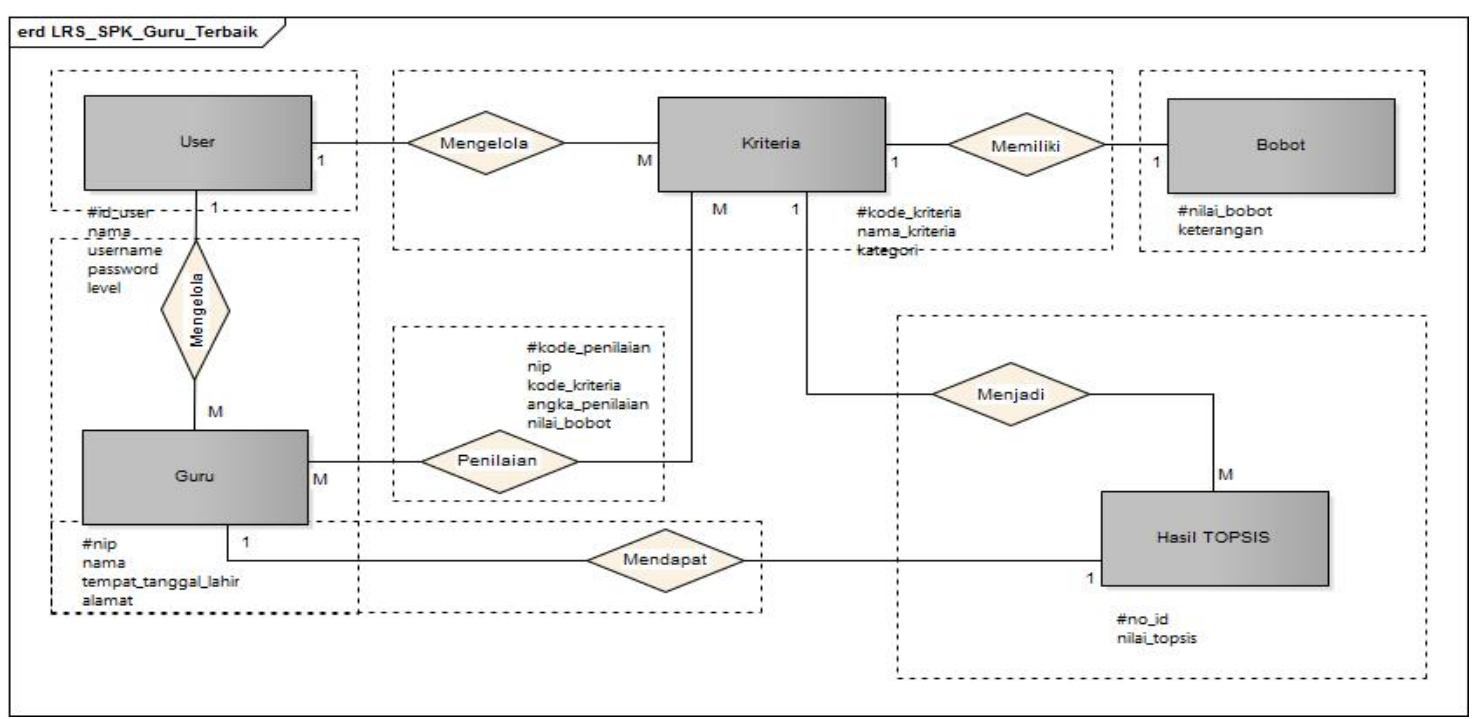

Gambar 9. Transformasi ERD ke LRS

\section{Perancangan Aplikasi}

Perancangan Aplikasi terbagi atas beberapa bagian diantaranya, Use Case Diagram dan Activity Diagram, Sequence Diagram, Class Diagram, Rancangan User Interface.

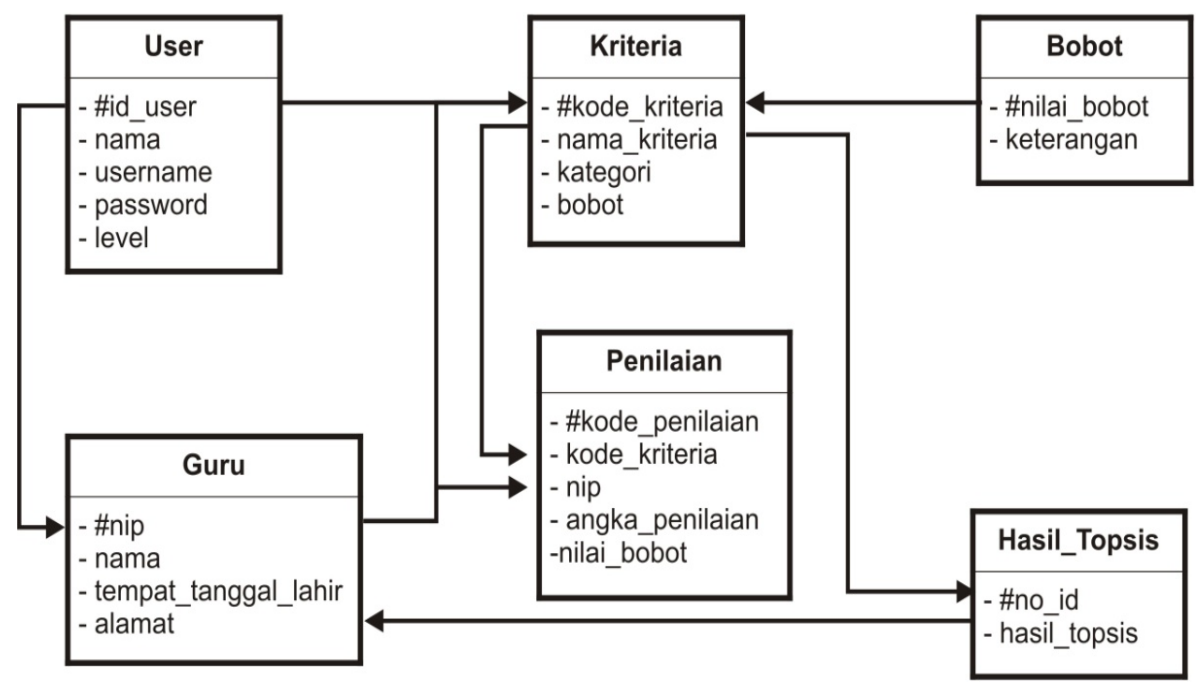

Gambar 10. Logical Record Structure

Tabel 8. Rancangan Tabel User

\begin{tabular}{|c|c|c|c|}
\hline Field & Type & Length & Indeks \\
\hline id_user & Varchar & 20 & Primary Key \\
\hline Nama & Varchar & 35 & - \\
\hline Username & Varchar & 15 & Unique \\
\hline Password & Varchar & 255 & - \\
\hline Level & Varchar & 15 & - \\
\hline
\end{tabular}


Fitri Duwiyanti, Maulana Ardhiansyah.

Decision Support System for Selection of the Best Teachers in SMK. Pustek Serpong.

International Journal of Education, Science, Technology and Engineering, vol. 2, no. 1, pp. 45-67, June 2019. DOI: 10.36079/lamintang.ijeste-0201.18

\subsection{Use Case Diagram}

Use case diagram dalam penelitian ini dapat dilihat pada Gambar 11, Gambar 12, Gambar 13, dan Gambar 14.

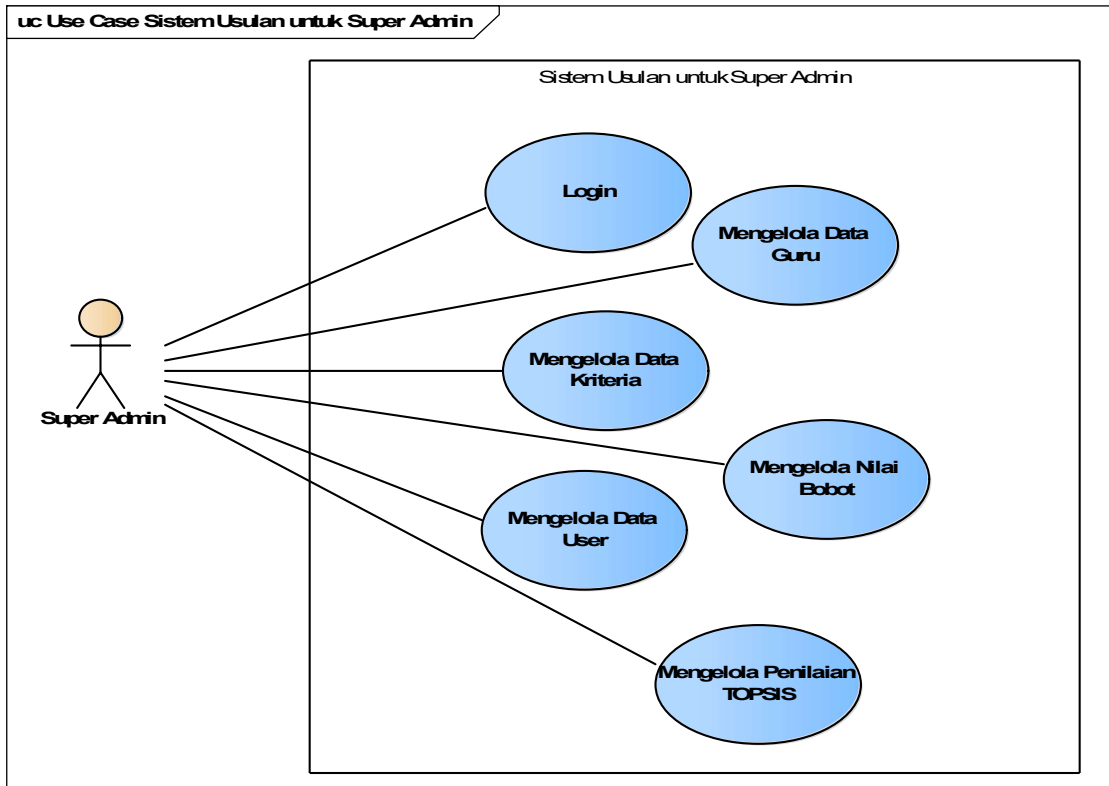

Gambar 11. Use Case Diagram Super Admin

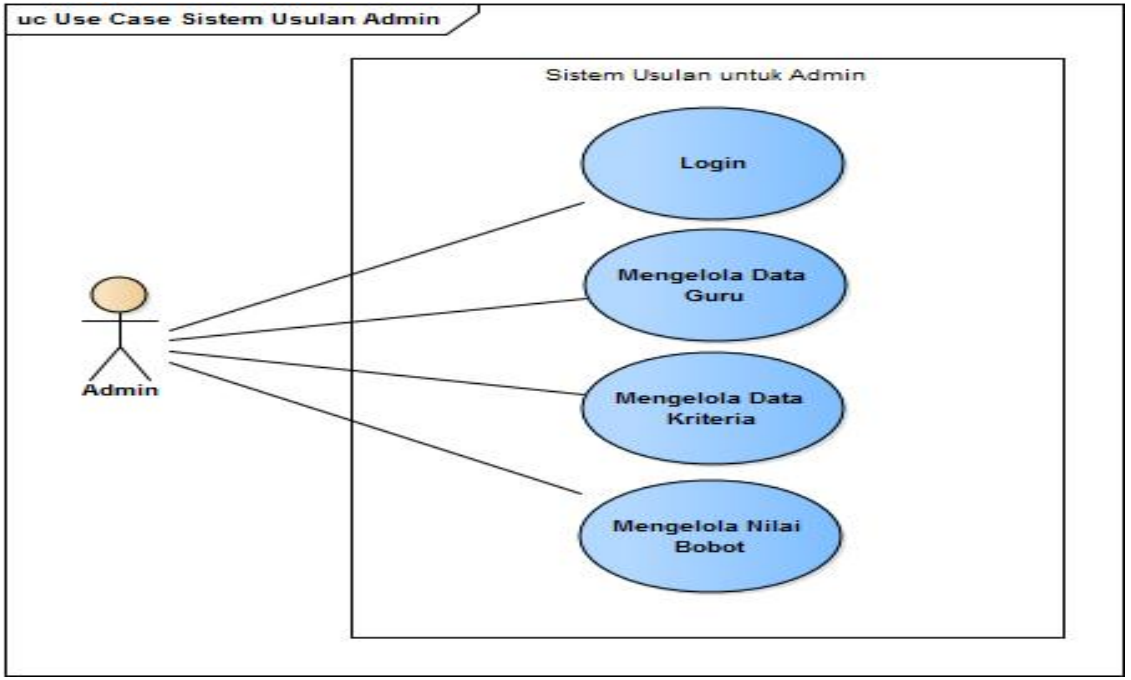

Gambar 12. Use Case Diagram Admin 


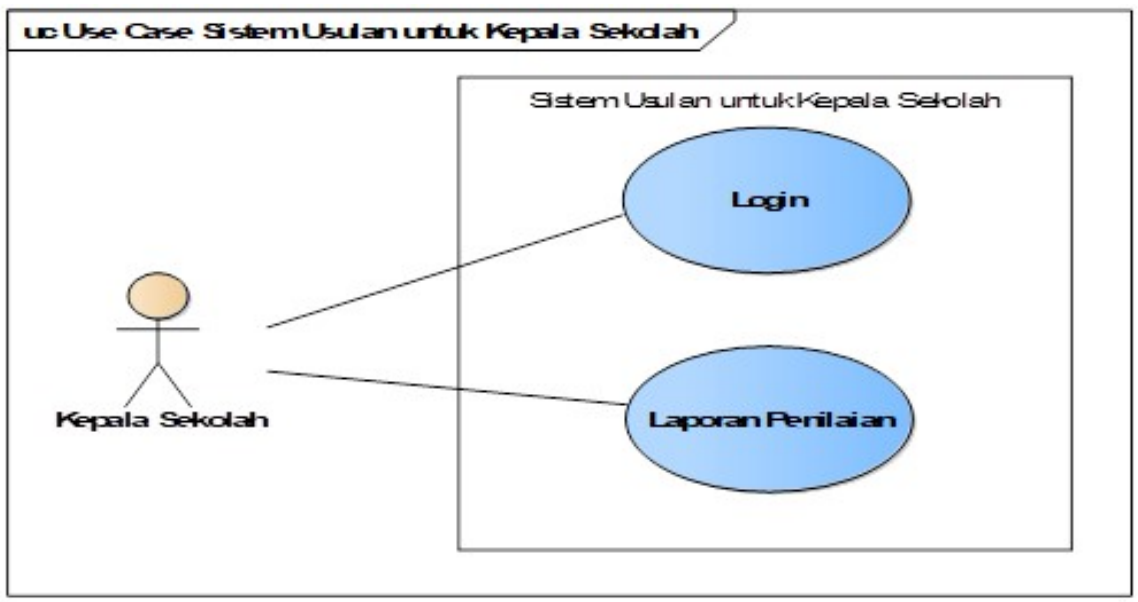

Gambar 13. Use Case Diagram Kepala Sekolah

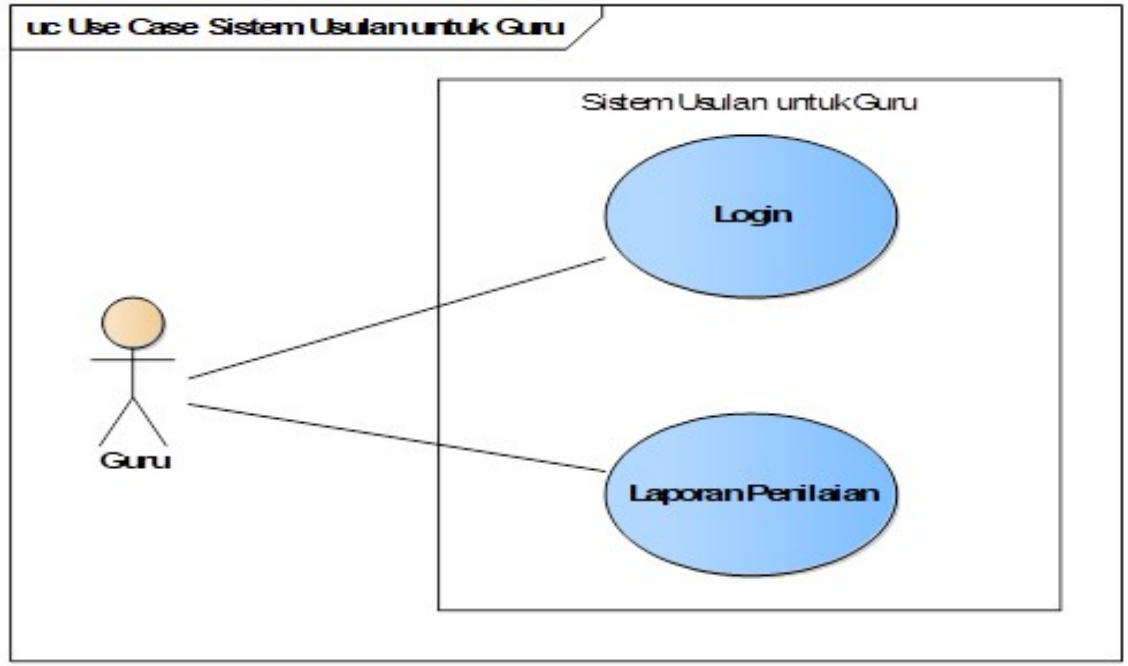

Gambar 14. Use Case Diagram Guru

\subsection{Activity Diagram}

Activity Diagram dalam penelitian ini terdiri atas Activity Diagram Login, Activity Diagram Mengelola Data Guru, Activity Diagram Mengelola Data Kriteria, Activity Diagram Mengelola Nilai Bobot, Activity Diagram Melakukan Penilaian SPK Guru Terbaik, Activity Diagram Laporan Penilaian. Contoh activity diagram dalam penelitian ini dapat dilihat pada Gambar 15.

Gambar 15 menjelaskan tentang kegiatan Login yang dilakukan oleh Admin dan Kepala Sekolah pada sistem pemilihan guru terbaik.

\subsection{Sequence Diagram}

Sequence Diagram dalam penelitian ini terdiri atas Sequence Diagram Kelola Data Bobot, Sequence Diagram Melakukan Penilaian SPK, Sequence Diagram Melihat Laporan Penilaian. Contoh Sequence Diagram dalam penelitian ini dapat dilihat pada Gambar 16.

Sequence diagram Login Pada Gambar 16 merupakan kegiatan yang dilakukan pada form Login dimana Admin/Kepala Sekolah memasukan username dan password. Username dan password harus sesuai dengan data yang ada pada database. 
Fitri Duwiyanti, Maulana Ardhiansyah.

Decision Support System for Selection of the Best Teachers in SMK. Pustek Serpong.

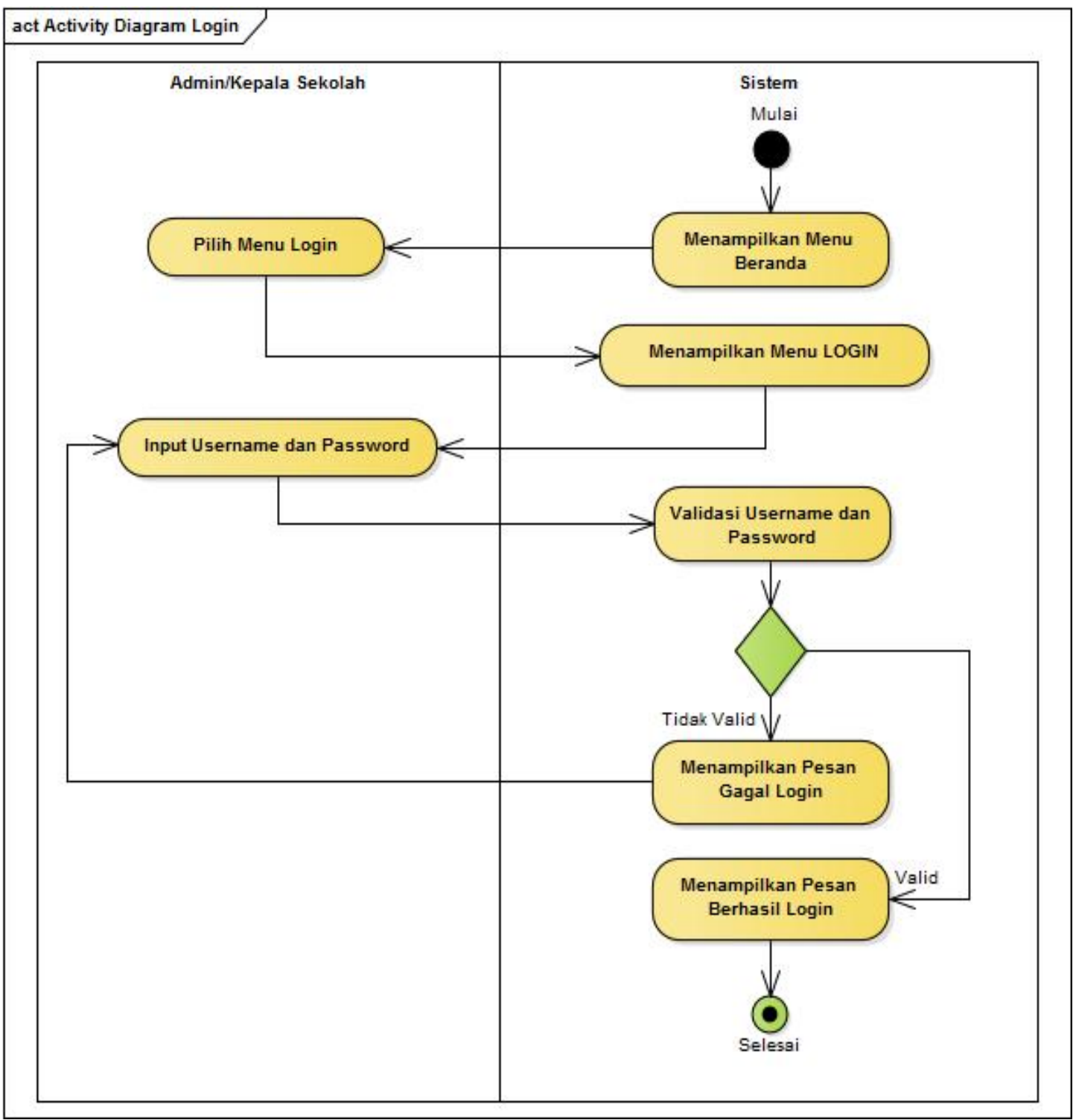

Gambar 15. Activity Diagram Login

\subsection{Class Diagram}

Class Diagram dalam penelitian ini dapat dilihat pada Gambar 17.

\section{Implementasi}

\subsection{Perangkat Keras dan Perangkat Lunak}

Untuk menjalankan website yang telah dirancang maka dibutuhkan perangkat keras sebagai tempat untuk menerapkannya. Adapun Perangkat keras yang dibutuhkan dapat dilihat pada Tabel 9 sednagkan perangkat lunak nya bisa dilihat pada Tabel 10 . 
Fitri Duwiyanti, Maulana Ardhiansyah.

Decision Support System for Selection of the Best Teachers in SMK. Pustek Serpong.

International Journal of Education, Science, Technology and Engineering, vol. 2, no. 1, pp. 45-67, June 2019. DOI: 10.36079/lamintang.ijeste-0201.18

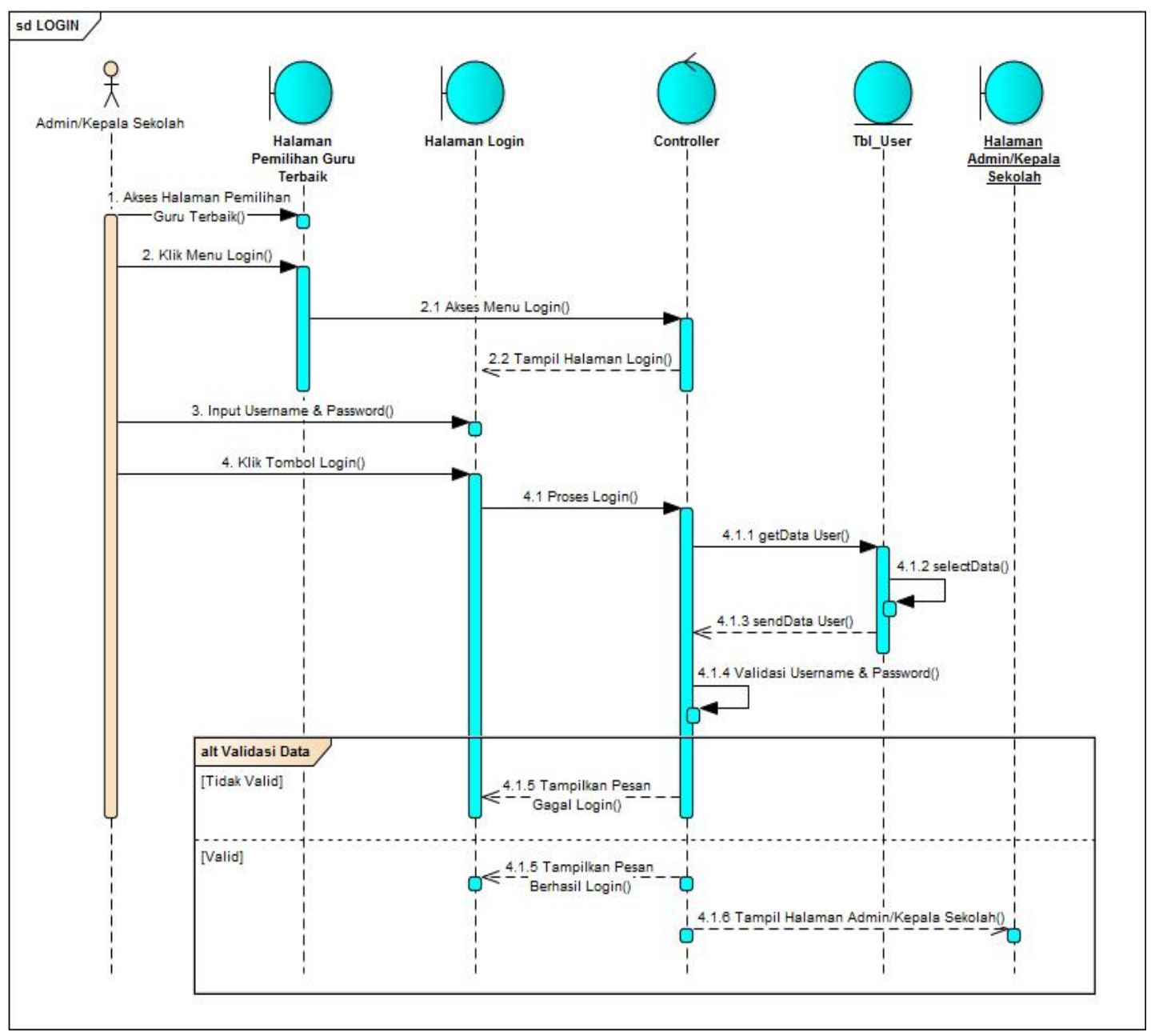

Gambar 16. Sequence Diagram Login

Tabel 9. Perangkat Keras

\begin{tabular}{|l|c|c|}
\hline No. & Nama & Spesifikasi Minimum \\
\hline 1. & Processor & AMD C-70 $1.00 \mathrm{GHz}$ (Atau setara). \\
\hline 2. & RAM & $2 \mathrm{~GB}$ \\
\hline 3. & Monitor & 11.3 " Radeon $^{\mathrm{TM}}$ HD Graphics \\
\hline
\end{tabular}

Tabel 10. Perangkat Lunak

\begin{tabular}{|l|c|c|}
\hline No. & Tools & Software Pendukung \\
\hline 1. & Web Browser & Mozilla Firefox 52.0.1 (32 bit) \\
\hline 2. & XAMPP & XAMPP for Windows 5.6.14 \\
\hline 3. & PHP & PHP Version 5.6.14 \\
\hline 4. & Database & MariaDB (MySQLi Extentions) \\
\hline
\end{tabular}


Fitri Duwiyanti, Maulana Ardhiansyah.

Decision Support System for Selection of the Best Teachers in SMK. Pustek Serpong.

International Journal of Education, Science, Technology and Engineering, vol. 2, no. 1, pp. 45-67, June 2019. DOI: 10.36079/lamintang.ijeste-0201.18

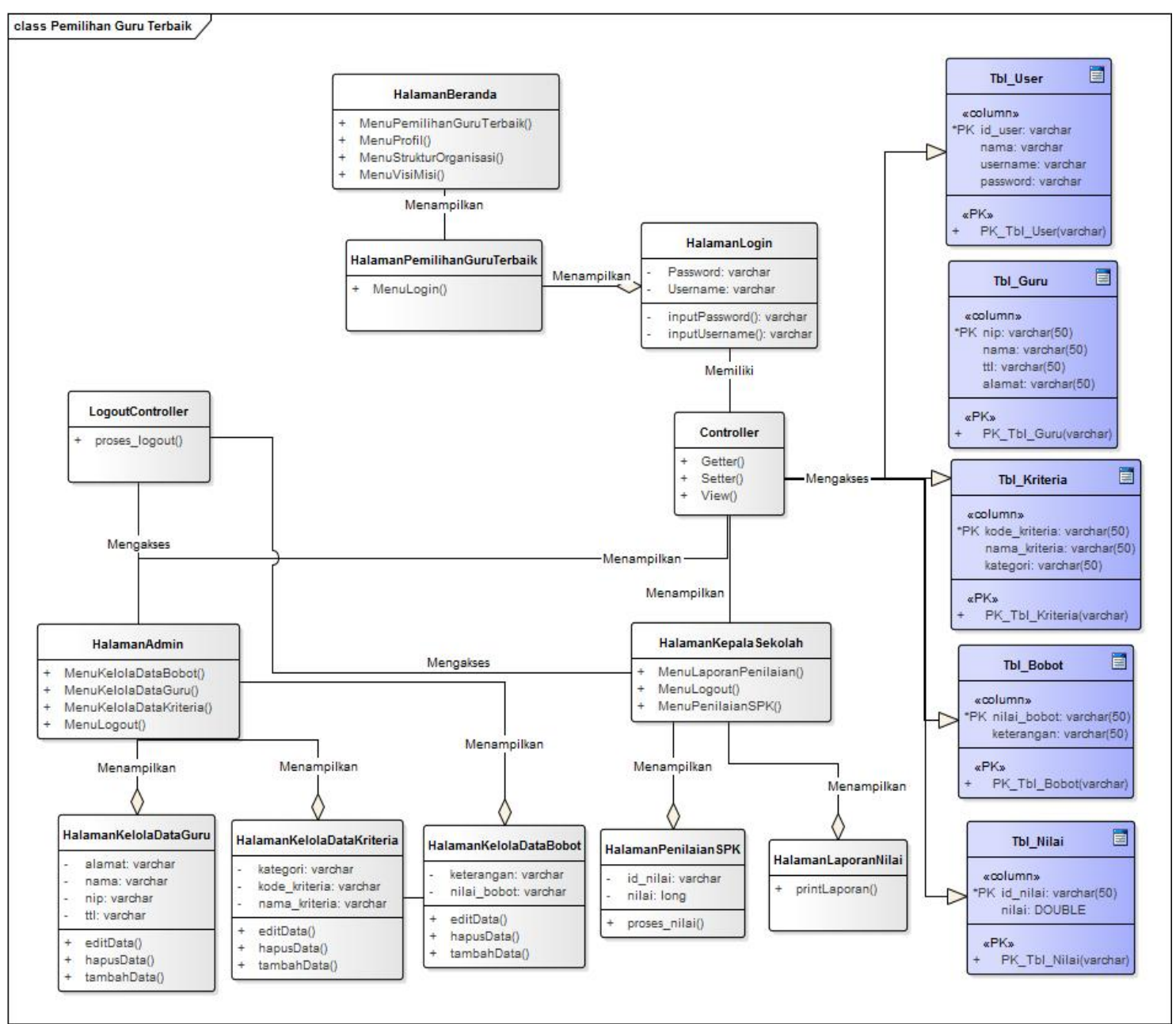

Gambar 17. Class Diagram Sistem Pemilihan Guru Terbaik

\subsection{Antarmuka}

Implementasi antarmuka dan penjelasan struktur menu pada halaman beranda Sistem Pemilihan Guru Terbaik dapat dilihat pada Gambar 18.

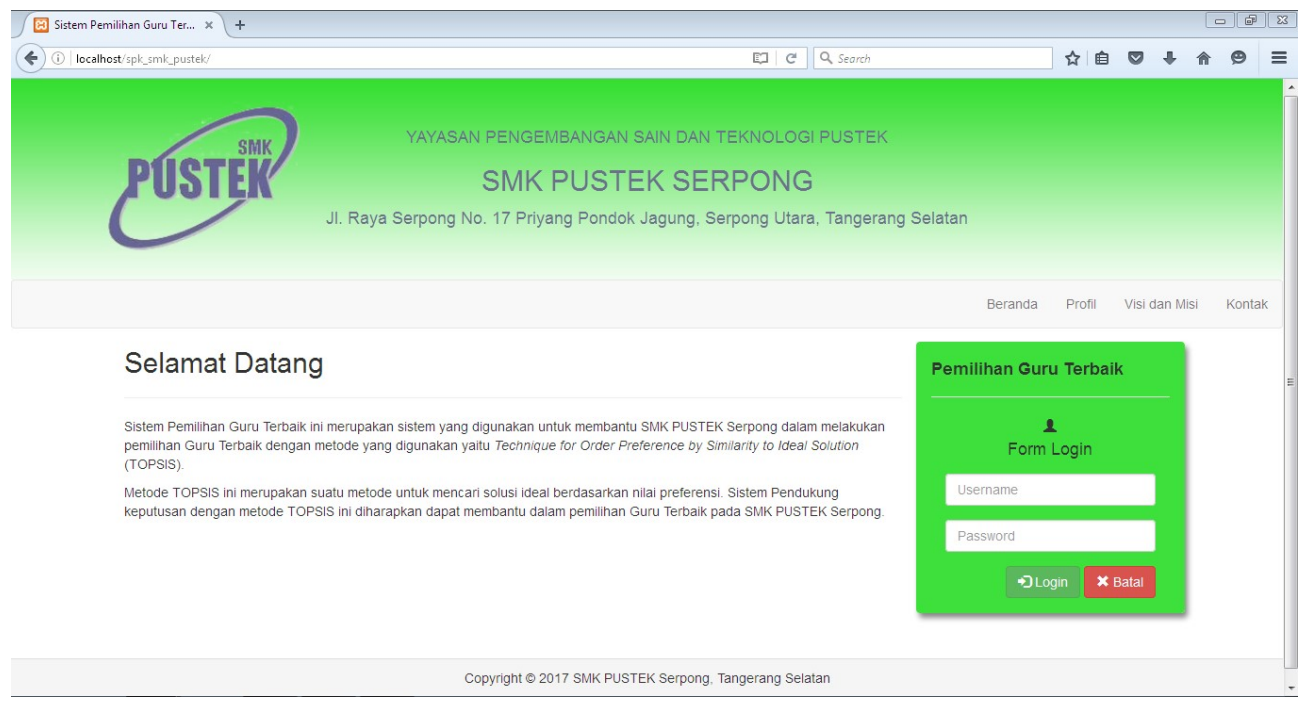

Gambar 18. Implementasi User Interface Halaman Beranda 


\section{Pengujian}

Pengujian sistem terdiri atas Blackbox dan Whitebox.

\subsection{Pengujian Blackbox}

Pengujian Blackbox merupakan pengujian software berfokus pada persyaratan fungsionalnya. Pengujian Sistem Pemilihan Guru Terbaik ini menggunakan data uji berupa data Input dari User pada sistem yang telah dibangun.

Tabel 11. Pengujian Black Box

\begin{tabular}{|c|c|}
\hline ITEM UJI & JENIS PENGUJIAN \\
\hline Login & Blackbox \\
\hline Kelola Data Guru & Blackbox \\
\hline Kelola Data Kriteria \& Bobot & Blackbox \\
\hline Kelola Data Users & Blackbox \\
\hline Penilaian TOPSIS & Blackbox \\
\hline Hasil Penilaian & Blackbox \\
\hline
\end{tabular}

\subsection{Pengujian Whitebox}

Pengujian Whitebox merupakan metode desain uji kasus yang menggunakan struktur control dari desain procedural untuk menghasilkan kasus-kasus uji. Pengujian Whitebox didesain untuk mengungkap kesalahan pada persyaratan fungsional tanpa mengabaikan kerja internal dari suatu software.

Pengujian White Box untuk sistem pemilihan guru terbaik diantaranya, untuk validasi data login user, untuk memproses fungsi simpan data guru, untuk memproses fungsi update data guru, untuk memproses fungsi hapus data guru, dan untuk memproses penilaian dan perhitungan TOPSIS.

\section{Kesimpulan}

Berdasarkan hasil perancangan, implementasi dan pengujian Sistem Pemilihan Guru Terbaik pada SMK Pustek Serpong dengan menerapkan metode Technique for Order Preference by Similarity to Ideal Solution (TOPSIS) untuk melakukan pemilihan guru terbaik, maka dapat diambil kesimpulan sebagai berikut:

1. Perancangan dan pembangunan Sistem Pemilihan Guru Terbaik terbukti dapat membantu SMK Pustek Serpong dalam melakukan pemilihan guru terbaik.

2. Penerapan metode Technique for Order Preference by Similarity to Ideal Solution (TOPSIS) terbukti dapat membantu Kepala Sekolah dalam pengambilan keputusan pemilihan guru terbaik sesuai dengan nilai yang telah ditentukan.

Dari hasil analisa dan perancangan sistem ini peneliti menyadari bahwa masih banyak kekurangan dan kesalahan dalam pembangunan sistem ini, dan berikut adalah beberapa saran yang diberikan untuk meningkatkan kemampuan dan fungsi dari sistem pada pengembangan yang lebih lanjut:

1. Diharapkan sistem ini dapat dikembangkan pada aplikasi berbasis mobile atau pun platform lainnya sehingga menjadi lebih fleksibel.

2. Diharapkan sistem ini dapat dikembangkan dengan menggunakan metode Sistem Pendukung Keputusan lain seperti metode SAW, WP, AHP dan sebagainya dalam menentukan pemilihan guru terbaik.

\section{Daftar Pustaka}

[1] Arbelia, "Penerapan Metode AHP dan TOPSIS Sebagai Sistem Pendukung Keputusan Dalam Menentukan Kenaikan Jabatan Bagi Karyawan," JIGI, vol. 20, no. 1, pp. 1-9, 2014.

[2] T. Mufizar, Susanto, and N. Nurjayanti, "Sistem Pendukung Keputusan Penilaian Kinerja Guru di SDN Mohammad Toha Menggunakan Metode Analytical Hierarchy Process (AHP)", in 
Konferensi Nasional Sistem \& Informatika 2015, STMIK STIKOM Bali, October 9-10 Oktober, 2015.

[3] S. Mallu, "Sistem Pendukung Keputusan Penentuan Karyawan Kontrak Menjadi Karyawan Tetap Menggunakan Metode TOPSIS," JITTER, vol. 1, no. 2, 2017.

[4] Munawar, Pemodelan Visual dengan UML. Yogyakarta: Graha Ilmu, 2005.

[5] Kusrini, Konsep dan Aplikasi Sistem Pendukung Keputusan. Yogyakarta: Penerbit And, 2007.

[6] E. Turban, Decision Support System and Intelligent Systems, Edisi 7. Yogyakarta: Penerbit Andi, 2005.

[7] S. Kusumadewi, and S. Hartati, Fuzzy Multi Attribute Decision Making (Fuzzy-MADM). Yogyakarta: Penerbit Andi, 2006.

[8] A. Abdillah, and Uriawan, "Sistem Pendukung Keputusan SEleksi Penerimaan Peserta Studepreneur Menggunakan Metode AHP dan TOPSIS," SENTIKA, 2016.

[9] S. Muhammad, and R. S. Ariani, Modul Rekayasa Perangkat Lunak (Terstruktur dan Berorientasi Objek). Bandung: Modula, 2011.

[10] Fathansyah, Basis Data. Bandung: Informatika, 2012. 